\title{
Os impactos do programa Minha Casa Minha Vida no trabalho na construção civil em Sumaré e Hortolândia
}

\section{William Loures da Costa}

\section{Resumo}

Este trabalho constitui-se em uma tentativa de ser analisar qual o impacto do Programa Minha Casa Minha Vida (PMCMV) na geração de empregos no setor da construção civil nos municípios de Sumaré e Hortolândia. Inicialmente, é realizada uma discussão qualitativa sobre a produção da habitação enquanto atividade capitalista, vinculada ao processo de valorização do capital, seguida por uma discussão acerca do caráter supostamente anticíclico do programa. Finalmente, expõem-se algum dados referentes à construção civil no Brasil e nos municípios de Sumaré e Hortolândia, dos anos anteriores à implantação do PMCMV até o ano de 2014.

\section{Palavras-chave}

Construção civil, emprego, política habitacional

\section{Introdução}

O PMCMV, lançado em 2009, foi anunciado como uma das principais medidas do governo para o combate à crise econômica. Caracterizado como uma política habitacional cuja proposta é a construção de habitações destinadas aos extratos populacionais de menor rendimento, foi também apresentado como uma importante medida para a economia, gerando empregos e fomentando investimentos no setor da construção civil.

Todavia, alguns questionamentos surgem quando pensamos em aspectos qualitativos da geração de empregos no programa. Arantes e Fix (2009) colocam em questão, por exemplo, o caráter anticíclico do programa, além das próprias condições de trabalho nos canteiros de obras dos empreendimentos. ${ }^{1}$

Para além da retomada, ainda que parcial, da discussão teórica crítica sobre a produção capitalista da moradia, este trabalho busca analisar alguns dados empíricos sobre a construção civil no Brasil e nos municípios de Sumaré e Hortolândia no período de implementação do programa. Inclui-se, nesse análise, a participação da construção no total de empregos gerados, a evolução dos saldos de empregos gerados no setor, além de outras questões como a formalização e a taxa de rotatividade.

\section{Resultados e Discussão}

Quanto à discussão qualitativa, o que se pôde depreender foi que há uma insuficiência das forças de mercado em resolver o problema da habitação em países como o Brasil. Ainda que o PMCMV pareça, em um primeiro momento, uma forma de criar condições para a inserção de extratos sociais de menor rendimento no mercado habitacional, essa inserção parece ser precária e insuficiente.

No que tange à análise empírica, pudemos ver que, no Brasil, o setor da construção civil de fato foi importante para "amortecer" os impactos da crise em 2009 , representando, naquele ano, quase $18 \%$ dos empregos formais gerados. No entanto, esta participação não se sustentou nos anos seguintes, voltando a uma participação menor do que a apresentada nos anos anteriores à implementação do programa.

Já em relação aos municípios de Sumaré e Hortolândia, pudemos ver que a geração de empregos se deu de forma diferente em cada caso, com Hortolândia apresentando um saldo de novos empregos que foi quase o dobro do de Sumaré no mesmo período. A Figura 1 compara a geração de empregos nos dois municípios.

Figura 1. Evolução do saldo do emprego formal na construção civil em Sumaré e Hortolândia

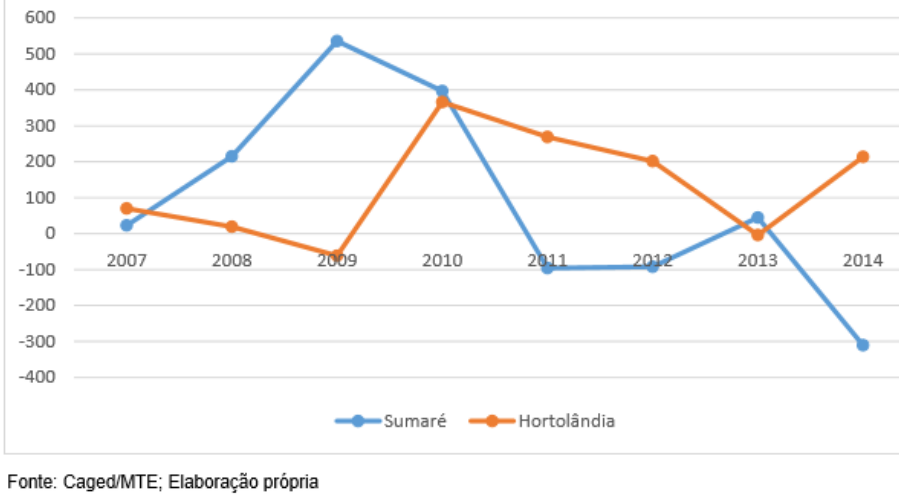

\section{Conclusões}

A pesquisa, pela complexidade do tema, deu-se de forma mais exploratória do que conclusiva. No entanto, é possível afirmar que, em relação aos municípios de Sumaré e Hortolândia, o impacto do programa foi mais favorável em relação ao segundo município, no que diz respeito à criação de empregos.

\section{Agradecimentos}

Agradeço, em primeiro lugar, ao CNPq, que, por meio do PIBIC, deu-me a oportunidade de ter um primeiro contato com a pesquisa acadêmica.

Devo agradecer, também, à professora Mariana Fix, cuja orientação foi fundamental para o desenvolvimento de minha pesquisa, e a meus colegas do grupo de pesquisa do CEDE, pelos debates e discussões.

Finalmente, agradeço meus pais, leda e Luís, por sempre me apoiarem e incentivarem.

Arantes, P. e Fix, M. Como o governo Lula pretende resolver o problema da habitação. 2009 